\title{
In vitro efficacy of two commercial products of Metarhizium anisopliae s.l. for controlling the cattle tick Rhipicephalus microplus
}

\author{
Eficácia in vitro de dois produtos comerciais de Metarhizium anisopliae s.l. no \\ controle do carrapato bovino Rhipicephalus microplus
}

\begin{abstract}
Michel Ruan dos Santos Nogueira'; Mariana Guedes Camargo'; Caio Junior Balduino Coutinho Rodrigues';

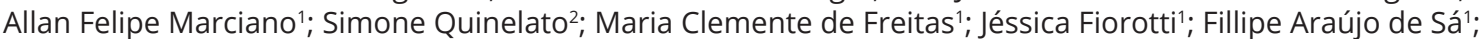
Wendell Marcelo de Souza Perinotto3; Vânia Rita Elias Pinheiro Bittencourt ${ }^{1 *}$ (D)

'Departamento de Parasitologia Animal, Instituto de Veterinária, Universidade Federal Rural do Rio de Janeiro - UFRRJ, Seropédica, RJ, Brasil ${ }^{2}$ Coleção de Culturas de Fungos Filamentosos, Instituto Oswaldo Cruz, Fundação Oswaldo Cruz - Fiocruz, Rio de Janeiro, RJ, Brasil ${ }^{3}$ Centro de Ciências Agrárias e Biológicas, Universidade Federal do Recôncavo da Bahia - UFRB, Cruz das Almas, BA, Brasil
\end{abstract}

How to cite: Nogueira MRS, Camargo MG, Coutinho Rodrigues CJB, Marciano AF, Quinelato S, Freitas MC, et al. In vitro efficacy of two commercial products of Metarhizium anisopliae s.I. for controlling the cattle tick Rhipicephalus microplus. Braz J Vet Parasitol 2020; 29(2): e000220. https://doi.org/10.1590/S1984-29612020035

\begin{abstract}
The effects of two different products - Metarril ${ }^{\circledR}$ SP Organic (dry conidia) and Metarril ${ }^{\circledR}$ SC Organic (emulsifiable concentrated conidia in vegetable oil) - on eggs, larvae and Rhipicephalus microplus engorged females were here explored. Three concentrations $\left(10^{8}, 10^{7}\right.$, and $10^{6}$ conidia $\left.\mathrm{mL}^{-1}\right)$ for both products were prepared in water $+0.1 \%$ Tween ${ }^{\circledR} 80(\mathrm{v} / \mathrm{V})$; afterward, bioassays were carried out for all R. microplus stages by immersion in suspensions (Metarri ${ }^{\circledR}$ SP) or formulations (Metarri ${ }^{\circledR}$ SC). Metarri ${ }^{\circledR}$ SP suspensions showed low efficacy and did not affect biological parameters of treated engorged females; for eggs and larvae, only slight decreases in hatchability and larvae population were observed. Despite a delay in germination, Metarri ${ }^{\circledR}$ SC presented better results; for females, reductions in Egg Mass Weight (EMW) and Egg Production Index (EPI) were reported. On eggs, $10^{8}$ conidia $\mathrm{mL}^{-1}$ increased Incubation Period (IP), shortened Hatching Period (HP) and decreased hatchability by up to $61 \%$; for larvae, $10^{7}$ and $10^{8}$ conidia $\mathrm{mL}^{-1}$ reached 99.6 and $100 \%$ larval mortality respectively, 10 days after fungal exposure. Thus, further studies involving the use of oil-based formulations for ticks such as Metarril ${ }^{\circledR}$ SC need to be performed, especially to control the most susceptible stages (eggs and larvae).
\end{abstract}

Keywords: Biological control, entomopathogenic fungus, oil-based formulation, cattle tick.

\section{Resumo}

No presente trabalho, os efeitos de dois diferentes produtos foram avaliados - Metarril ${ }^{\circledast}$ SP Organic (conídios secos) e Metarril ${ }^{\circledR}$ SC Organic (conídios concentrados em óleo vegetal) - para ovos, larvas e fêmeas ingurgitadas de Rhipicephalus microplus. Três concentrações $\left(10^{8}, 10^{7}\right.$ e $10^{6}$ conídios $\left.\mathrm{mL}^{-1}\right)$ para cada produto foram preparadas em água + Tween ${ }^{\circledast} 80$ 0,1\% (v/v); os bioensaios foram realizados para todos os estágios de $R$. microplus por imersão nas suspensões (Metarril ${ }^{\circledast}$ SP) ou formulações (Metarril ${ }^{\circledast}$ SC). Metarril ${ }^{\circledast}$ SP não afetou os parâmetros biológicos das fêmeas, demonstrando assim baixa eficácia; para ovos e larvas, foram observadas discretas diminuições na eclodibilidade e na população de larvas. Apesar de um atraso na germinação, Metarril ${ }^{\circledR}$ SC apresentou melhores resultados; para as fêmeas, foram detectadas reduções no Peso da Massa de Ovos (PMO) e no Índice de Produção de Ovos (IPO). Para os ovos, a concentração de $10^{8}$ conídios $\mathrm{mL}^{-1}$ aumentou o Período de Incubação (PI), reduziu o Período de Eclosão (PE) e também o da eclodibilidade em até 61\%; para larvas, $10^{7}$ e $10^{8}$ conídios $\mathrm{mL}^{-1}$ atingiram 99,6 e 100\% de mortalidade larval, respectivamente, 10 dias após a exposição fúngica. Com isso, estudos adicionais que envolvem o uso de formulações à base de óleo para carrapatos, como Metarril ${ }^{\circledR} \mathrm{SC}$, precisam ser realizados, especialmente para controlar os estágios mais suscetíveis (ovos e larvas).

Palavras-chave: Controle biológico, fungo entomopatogênico, formulação oleosa, carrapato bovino.

Received January 16, 2020. Accepted April 20, 2020

*Corresponding author: Vânia Rita Elias Pinheiro Bittencourt. E-mail: vaniabit@ufrrj.br 


\section{Introduction}

Commonly affecting livestock production, Rhipicephalus microplus (Canestrini 1888) (Acari: Ixodidae) infestations lead to huge economic losses in Brazil (Grisi et al., 2014). The main tick control method includes a widespread application of chemicals; however, indiscriminate usage of these molecules not only result in reductions on efficacy and tick resistance (Abbas et al., 2014; Reck et al., 2014; Klafke et al., 2017) but also pose a risk to the environment and human health (Pignati et al., 2017). Regarding some alternatives, new techniques for tick-controlling have been constantly investigated including vaccines (Merino et al., 2013), herbal products (Ghosh et al., 2015), and entomopathogenic fungi (Fernandes et al., 2012).

As an important biopesticide, Metarhizium spp. are applied in the field to control some arthropods (Aw \& Hue, 2017); it is known about its low non-target impacts and high safety for mammals, birds, aquatic animals and plants (Zimmermann, 2007). This fungus affects all R. microplus stages (Fernandes et al., 2012; Quinelato et al., 2012; Mascarin et al., 2019) and its good performance is totally dependent on the environmental conditions (Jackson et al., 2010; Camargo et al., 2016; Ment et al., 2017; Tomer et al., 2018). In order to minimize these impediments, formulations are investigated by several researchers over the years, and the commercial production has greatly increased (Kaay \& Hassan, 2000; Faria \& Wraight, 2007; Kaaya et al., 2011; Camargo et al., 2016; Beys-da-Silva et al., 2020). There are 82 microbial pesticide products registered in Brazil, being $60 \%$ originally composed of fungi and none officially registered for ticks. Most formulations use conidia as the base, which may have or not some adjuvant added (Mascarin et al., 2019). In this regard, oil-based formulations improve efficacy and promote protection against environmental challenges (Samish et al., 2014).

This paper reports the in vitro efficacy in controlling R. microplus by testing two products from Koppert ${ }^{\circledR}$ Biological Systems (formerly Itaforte Bioproducts - Piracicaba, São Paulo, Brazil) based on M. anisopliae s.l. primarily indicated to agricultural pests. Since Itaforte ${ }^{\circledR}$ was purchased by Koopert ${ }^{\circledast}$ (Alves et al., 2017), many formulations of Metarril ${ }^{\circledR}$ have been revised and currently, Metarril ${ }^{\circledR}$ SP and Metarril ${ }^{\circledR}$ SC are no longer accessible commercially in Brazil (Mascarin et al., 2019). However, all tests of this study were done before Koppert ${ }^{\circledR}$ stopped producing and/or marketing these products. The effects of both formulations at different concentrations on all tick stages were explored, contributing then to better understanding the tick control using commercial products based on fungi.

\section{Material and Methods}

The experiments were performed at Federal Rural University of Rio de Janeiro (UFRRJ), Seropédica, RJ, Brazil [Department of Animal Parasitology, Veterinary Institute]. Two different products not yet registered for tick control in Brazil - based on M. anisopliae s.l. conidia - were used according to manufacturer's directions: Metarril ${ }^{\circledR}$ SP Organic (a mixture of two M. anisopliae s.l. strains - ESALQ 1037 and E9 - suspended in water) and Metarril ${ }^{\otimes}$ SC Organic (ESALQ 1037 strain in emulsifiable concentrated conidia in vegetable oil). For both products, three concentrations of fungi $\left(10^{8}, 10^{7}\right.$ and $10^{6}$ conidia $\left.\mathrm{mL}^{-1}\right)$ were prepared in $0.1 \%$ Tween ${ }^{\circledR} 80$ (v/v - diluent); and aqueous suspensions (Metarril ${ }^{\otimes} \mathrm{SP}$ ) and oil formulations (Metarril ${ }^{\otimes} \mathrm{SC}$ ) were vigorously homogenized and quantified using a hemocytometer. As a control, in Metarril ${ }^{\circledR}$ SP assays, only the diluent was used; for Metarril ${ }^{\otimes}$ SC, the emulsifiable vegetable oil present in the product was gently supplied by the company and diluted 10 (oil control 3), 100 (oil control 2), and 1000 times (oil control 1) in order to follow the same oil proportions found in the fungal oil suspensions.

Conidial germination was assessed from $10 \mu \mathrm{L}$ aliquots of each aqueous suspension or oil formulation $\left(10^{6}\right.$ conidia $\left.\mathrm{mL}^{-1}\right)$ dripped on Potato Dextrose Agar (PDA) $+0.05 \%$ chloramphenicol (CAP) (Kasvi $\left.{ }^{\circledR}\right)$. The plates were kept in dark $\left(25 \pm 1{ }^{\circ} \mathrm{C}\right.$ and relative humidity $\left.(\mathrm{RH}) \geq 80 \%\right)$. After 24 or 48 hours, $10 \mu \mathrm{L}$ lactophenol cotton blue was placed directly over the inoculum and covered with a glass coverslip. Then, viability was achieved by counting $3 \times 100$ conidia using a light microscope. Conidia were considered germinated if the germ tube was at least twice the width of the conidia (Hywel-Jones \& Gillespie, 1990).

In the bioassays, $R$. microplus engorged females were obtained by artificial infestation in calves [Research Permit $n^{\circ} 133 / 2014$ - Animal Ethics Committee/ UFRRJ] and collected from the stall floor, being sanitized in $0.1 \%$ sodium hypochlorite solution. For females' assays, ticks were separated into ten groups with ten specimens each according to Yule formula $(n c=2.5 \sqrt{ } N$ ), where $n c$ is the number of classes and $N$ is the number of variables (Sampaio, 2015). The treatment was made by immersion of females in one $\mathrm{mL}$ control, aqueous suspension or oil formulation for three min. After, females were kept at $27 \pm 1{ }^{\circ} \mathrm{C}$ and $\mathrm{RH} \geq 80 \%$, all eggs from each group weighed daily and the Egg Mass Weight (EMW), Nutrient Index (NI) and Egg Production Index (EPI) assessed (Bennett, 1974). Finally, the efficacy (\% Control) were calculated for each treatment taking into account their respective controls (Drummond et al., 1971). 
Some females were used to obtain eggs and larvae to the other trials. Fifty mg were placed into test tubes and sealed with hydrophilic cotton to assess the efficacy for eggs. One $\mathrm{mL}$ of each product or control was added to each tube and the egg masses were submerged for three min. After, all tubes were turned upside down and the excess absorbed (Quinelato et al., 2012). Eggs were kept at $27 \pm 1^{\circ} \mathrm{C}$ and $\mathrm{RH} \geq 80 \%$ and Incubation Period (IP), Hatching Period (HP), and Hatchability (\%) were evaluated up to thirty days after fungal exposure.

The effects on larvae were assessed from $50 \mathrm{mg}$ of eggs (approximately 1000 larvae) weighed into test tubes. Only tubes with hatchability greater than $95 \%$ were used in the trials. Larvae were also treated with one $\mathrm{mL}$ of each product or control and submerged for three min. The excess was after drained and larval mortality evaluated every five days until 15 days (Quinelato et al., 2012).

The fungal re-isolation from eggs (those from which larvae did not hatch), dead larvae and colonized engorged females were performed on PDA $+0.05 \%$ CAP and kept at $25 \pm 1{ }^{\circ} \mathrm{C}$ and $\mathrm{RH} \geq 80 \%$ for 14 days. Fungal colony growth was examined and morphologically classified as Metarhizium species (Bischoff et al., 2009).

Data were submitted to statistical analysis using InStat ${ }^{\circledR} 3.0$ (GraphPad Software, San Diego, California). After normality tests (Shapiro-Wilk), variance analysis (one-way ANOVA) followed by Tukey's post hoc test (parametric data) or Kruskal-Wallis followed by Dunn's Multiple Comparison Test (non-parametric data) were applied for determining the differences $(p<0.05)$.

\section{Results}

A delay in germination was observed to Metarri ${ }^{\circledR}$ SC; although conidia from Metarril ${ }^{\otimes}$ SP germinated up to $100 \%$ $24 \mathrm{~h}$ post-inoculation, conidia from Metarril ${ }^{\otimes}$ SC only fully germinated $48 \mathrm{~h}$ after incubation.

Metarril ${ }^{\circledR}$ SP did not affect the biological parameters of treated engorged females, showing low efficacy. In contrast, Metarril ${ }^{\circledR}$ SC, in some concentrations, was able to reduce EMW and/or EPI (Table 1). Regarding NI, Metarril ${ }^{\circledR}$ $\mathrm{SP}$ at $10^{7}$ and $10^{8}$ conidia $\mathrm{mL}^{-1}$ was able to decrease this parameter and for Metarril ${ }^{\circledR} \mathrm{SC}$, NI were not altered at any concentration tested. Percent Control is demonstrated in Figure 1, where Metarril SC at $10^{8} \mathrm{conidia} \mathrm{mL}^{-1}$ had the highest percent control.

On eggs, Metarril ${ }^{\otimes}$ SP only decreased hatchability by 12 to $24 \%$ after treatment. For Metarril ${ }^{\otimes}$ SC, $10^{8}$ conidia $\mathrm{mL}^{-1}$ demonstrated the best results, increasing IP, shortening HP around 2 days and decreasing hatchability by up to $61 \%$ (Table 2 ).

The larval stage was the most affected by fungal exposure. Metarri ${ }^{\circledR}$ SP showed reductions on larvae population by two ( $10^{\text {th }}$ day) and five ( $15^{\text {th }}$ day) times at its highest concentration. Metarril ${ }^{\circledR}$ SC achieved the most significant results, reaching at $10^{7}$ and $10^{8}$ conidia $\mathrm{mL}^{-1}$ complete or near-complete larval mortality within 10 days of treatment (Table 3).

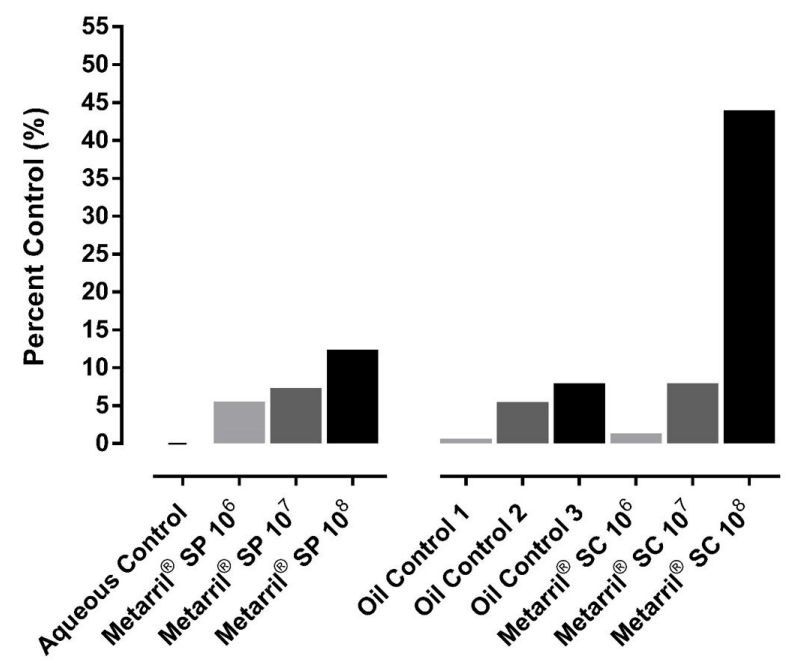

Figure 1. Percent Control (\% Control) of Rhipicephalus microplus engorged females exposed to Metarril ${ }^{\circledR}$ SP suspensions and Metarril ${ }^{\circledR}$ SC formulations $\left(10^{6}, 10^{7}\right.$ and $10^{8}$ conidia $\left.\mathrm{mL}^{-1}\right)$. The emulsifiable vegetable oil was diluted 10 times (Oil Control 3), 100 times (Oil Control 2), and 1000 times (Oil Control 1). 
Table 1. Egg Mass Weight (EMW), Egg Production Index (EPI) and Nutrient Index (NI) of engorged Rhipicephalus microplus females

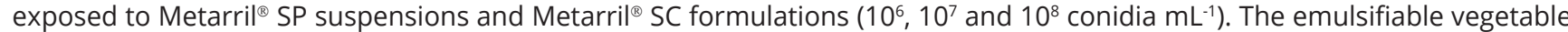
oil was diluted 10 times (Oil Control 3), 100 times (Oil Control 2), and 1000 times (Oil Control 1).

\begin{tabular}{|c|c|c|c|}
\hline Groups & $\operatorname{EMW}(g)^{1}$ & $\operatorname{EPI}(\%)^{2}$ & NI $(\%)^{1}$ \\
\hline Aqueous Control & $0.1664 \pm 0.025 a$ & $62.94 \pm 4.94 \mathrm{a}$ & $80.91 \pm 4.73 \mathrm{a}$ \\
\hline Metarril $^{\circledR}$ SP $10^{6}$ & $0.1591 \pm 0.019 a$ & $60.68 \pm 5.54 \mathrm{ab}$ & $79.12 \pm 3.76 \mathrm{a}$ \\
\hline Metarril $^{\circledR}$ SP $10^{7}$ & $0.1617 \pm 0.022 a$ & $58.76 \pm 5.80 \mathrm{ab}$ & $75.36 \pm 5.31 b$ \\
\hline Metarril $^{\circledR}$ SP $10^{8}$ & $0.1665 \pm 0.022 a$ & $62.47 \pm 4.20 a$ & $74.56 \pm 8.20 a b$ \\
\hline Oil Control 1 & $0.1689 \pm 0.015 a$ & $63.09 \pm 3.39 \mathrm{ab}$ & $81.61 \pm 3.59 a$ \\
\hline Oil Control 2 & $0.1594 \pm 0.023 a$ & $59.76 \pm 6.09 a b$ & $76.00 \pm 4.41 \mathrm{ab}$ \\
\hline Oil Control 3 & $0.1658 \pm 0.022 a$ & $61.88 \pm 3.30 a b$ & $73.89 \pm 3.52 \mathrm{ab}$ \\
\hline Metarril $^{\circledR}$ SC $10^{6}$ & $0.1695 \pm 0.022 a$ & $63.04 \pm 4.25 \mathrm{a}$ & $78.37 \pm 6.57 \mathrm{ab}$ \\
\hline Metarril $^{\circledR}$ SC $10^{7}$ & $0.1465 \pm 0.026 a b$ & $55.18 \pm 8.98 b$ & $75.66 \pm 8.48 a b$ \\
\hline Metarril ${ }^{\circledR}$ SC $10^{8}$ & $0.1262 \pm 0.026 b$ & $45.74 \pm 9.17 c$ & $68.40 \pm 3.12 a b$ \\
\hline
\end{tabular}

Mean \pm standard deviation with the same letter, in the same column, did not differ by variance analysis (one-way ANOVA) followed by Tukey's post hoc test ${ }^{1}$ or by Kruskal-Wallis followed by Dunn's Multiple Comparison Test ${ }^{2}(p \geq 0.05)$. Bioassays were repeated twice (10 females each).

Table 2. Incubation Period (IP), Hatching Period (HP), and Hatchability (\%) of Rhipicephalus microplus eggs exposed to Metarril ${ }^{\circledR}$ SP suspensions and Metarril ${ }^{\circledR}$ SC formulations $\left(10^{6}, 10^{7}\right.$ and $10^{8}$ conidia $\left.\mathrm{mL}^{-1}\right)$. The emulsifiable vegetable oil was diluted 10 times (Oil Control 3), 100 times (Oil Control 2), and 1000 times (Oil Control 1).

\begin{tabular}{|c|c|c|c|}
\hline Groups & IP (days) ${ }^{1}$ & HP (days) ${ }^{2}$ & Hatchability $(\%)^{2}$ \\
\hline Aqueous Control & $24.80 \pm 1.14 a$ & $14.70 \pm 0.95 a$ & $98.00 \pm 1.70 a$ \\
\hline Metarril ${ }^{\otimes}$ SP $10^{6}$ & $24.70 \pm 0.95 a$ & $15.40 \pm 0.84 a$ & $86.00 \pm 3.94 b$ \\
\hline Metarril ${ }^{\circledR}$ SP $10^{7}$ & $25.30 \pm 0.48 a b$ & $14.80 \pm 0.63 a$ & $84.00 \pm 5.16 b$ \\
\hline Metarril ${ }^{\circledR}$ SP $10^{8}$ & $24.90 \pm 0.99 a$ & $15.20 \pm 0.92 a$ & $74.00 \pm 3.94 c$ \\
\hline Oil Control 1 & $24.60 \pm 0.84 a$ & $15.30 \pm 0.95 a$ & $89.40 \pm 3.44 a$ \\
\hline Oil Control 2 & $25.50 \pm 0.71 \mathrm{ab}$ & $15.50 \pm 0.71 a$ & $93.00 \pm 3.17 a$ \\
\hline Oil Control 3 & $24.80 \pm 0.63 a$ & $14.80 \pm 0.92 a$ & $93.00 \pm 4.04 \mathrm{a}$ \\
\hline Metarril $^{\circledast}$ SC $10^{6}$ & $25.60 \pm 0.70 a b$ & $14.50 \pm 0.71 a$ & $85.00 \pm 3.33 b$ \\
\hline Metarril $^{\circledR}$ SC $10^{7}$ & $24.70 \pm 0.95 a$ & $15.20 \pm 0.92 a$ & $82.00 \pm 4.12 b$ \\
\hline Metarril $^{\circledR}$ SC $10^{8}$ & $26.60 \pm 1.58 b$ & $12.60 \pm 2.76 b$ & $36.00 \pm 8.43 d$ \\
\hline
\end{tabular}

Mean \pm standard deviation with the same letter, in the same column, did not differ by variance analysis (one-way ANOVA) followed by Tukey's post hoc test ${ }^{1}$ or by Kruskal-Wallis followed by Dunn's Multiple Comparison Test ${ }^{2}(p \geq 0.05)$. Bioassays were repeated twice (10 test tubes each).

Table 3. Larval Mortality (\%) on $5^{\text {th }}, 10^{\text {th }}$ and $15^{\text {th }}$ days after Rhipicephalus microplus larvae exposure to Metarril ${ }^{\circledR}$ SP suspensions and Metarri ${ }^{\otimes}$ SC formulations $\left(10^{6}, 10^{7}\right.$ and $10^{8}$ conidia $\left.\mathrm{mL}^{-1}\right)$. The emulsifiable vegetable oil was diluted 10 times (Oil Control 3 ), 100 times (Oil Control 2), and 1000 times (Oil Control 1).

\begin{tabular}{|c|c|c|c|}
\hline Groups & $5^{\text {th }}$ day & $10^{\text {th }}$ day & $15^{\text {th }}$ day \\
\hline Aqueous Control & $0.30 \pm 0.24 a b$ & $4.00 \pm 3.41 \mathrm{a}$ & $6.90 \pm 4.95 a$ \\
\hline Metarril ${ }^{\circledR}$ SP $10^{6}$ & $0.00 \pm 0.00 a$ & $3.40 \pm 2.80 a$ & $8.50 \pm 6.41 \mathrm{a}$ \\
\hline Metarril ${ }^{\circledR}$ SP $10^{7}$ & $0.00 \pm 0.00 \mathrm{a}$ & $4.10 \pm 2.39 a$ & $12.60 \pm 5.24 a$ \\
\hline Metarril ${ }^{\circledR}$ SP $10^{8}$ & $1.00 \pm 1.18 \mathrm{ab}$ & $8.90 \pm 5.36 b$ & $39.70 \pm 22.15 b$ \\
\hline Oil Control 1 & $0.70 \pm 0.75 a b$ & $1.20 \pm 0.60 \mathrm{a}$ & $1.90 \pm 1.58 \mathrm{a}$ \\
\hline Oil Control 2 & $3.20 \pm 3.85 a b$ & $3.50 \pm 1.32 \mathrm{a}$ & $13.13 \pm 16.11 \mathrm{a}$ \\
\hline Oil Control 3 & $3.20 \pm 6.31 \mathrm{ab}$ & $3.11 \pm 2.88 \mathrm{a}$ & $15.13 \pm 11.49 a$ \\
\hline Metarril ${ }^{\circledR}$ SC $10^{6}$ & $1.60 \pm 2.81 b$ & $8.60 \pm 1.96 b$ & $32.50 \pm 13.46 b$ \\
\hline Metarril $^{\circledR}$ SC $10^{7}$ & $69.50 \pm 26.97 c$ & $99.50 \pm 0.92 c$ & $99.60 \pm 0.92 c$ \\
\hline Metarril ${ }^{\circledR}$ SC $10^{8}$ & $86.67 \pm 9.72 c$ & $100.00 \pm 0.00 c$ & $100.00 \pm 0.00 c$ \\
\hline
\end{tabular}

Mean \pm standard deviation with the same letter, in the same column, did not differ by Kruskal-Wallis followed by Dunn's Multiple Comparison Test $(p \geq 0.05)$. Bioassays were repeated twice (10 test tubes each). 


\section{Discussion}

Even few agricultural policies encouraging the tick biocontrol in Brazil, it has noticeably increased the use of entomopathogenic fungi as biopesticides (Faria \& Wraight, 2007; Mascarin et al., 2019; Beys-da-Silva et al., 2020). Facing this challenge, progress has been achieved using different Metarril ${ }^{\otimes}$ formulations in in vitro trials for different tick species such as $R$. sanguineus (Alves et al., 2017), Dermacentor nitens (Perinotto et al., 2013) and Amblyomma sculptum (= A. cajennense s.l) (Lopes et al., 2007). Additionally, our findings endorse that in the laboratory, the oil formulation (Metarril ${ }^{\otimes} \mathrm{SC}$ ) outperforms the aqueous suspension (Metarril ${ }^{\otimes} \mathrm{SP}$ ) for R. microplus, particularly at $10^{8}$ conidia $\mathrm{mL}^{-1}$. Even though the relatively low Metarhizium spp. speed to kill ticks (Mascarin et al., 2019), the use of oil-based formulations has promoted host-pathogen interaction (Prior et al., 1988; Polar et al., 2005). Furthermore, oil-based formulations can protect the conidia of $M$. anisopliae from the adverse effects of high temperatures (Oliveira et al., 2018). Despite these advances and the recent review made on all products developed by Koppert ${ }^{\circledR}$ (Alves et al., 2017; Mascarin et al., 2019), improvements in tick fungal formulations are expected particularly adding oils in their compositions, while, on the one hand, large amounts of conidia may make bioproduction more expensive, but on the other, oily fungal products have shown to enhance efficacy. As an example, the addition of mineral oil to Metarril ${ }^{\circledR}$ SP allowed a percent control higher than $45 \%$ on $R$. microplus engorged females after two treatments on naturally infested animals (Camargo et al., 2016). In a different approach, the spread of fungal pellets on soil - against engorged females that drop from the host - has been innovatively developed, but these results need yet to be improved before large-scale applications (Mascarin et al., 2019).

Viability is one of the fungal efficacy predictors; it is advisable that conidial germination should be evaluated (even for commercial products) before the trials to guarantee reliable results. Although both products were under the same storage instructions (kept in the fridge at $4^{\circ} \mathrm{C}$ ), an expected delay in germination was observed to Metarril ${ }^{\circledR}$ SC. Similar effects were found when $M$. anisopliae s.I and B. bassiana s.I suspensions plus 10, 15, or $20 \%$ mineral oil were used to control $R$. microplus (Camargo et al., 2012). Interestingly, this delay did not influence the effects on ticks; we assume for this fact that oil may form a barrier between fungi and media, resulting in a long time for conidia to fully germinate. In tandem, oils added in tick fungal formulations by producing micelles can provide moisture to conidia due to its low volatility (Kaaya et al., 2011; Beys-da-Silva, et al., 2020) as well as help protecting against high temperatures (Barreto et al., 2016) and UV radiation (Hedimbi et al., 2008). By inserting mineral oil into Metarril ${ }^{\otimes}$ SP suspensions to control $R$. sanguineus, attractive results ensuring high germination percentages even after heat-stress were attained (Alves et al., 2017). Here, we certified the germination delay on culture medium; however, it could be assumed the same occurred on the cuticle surface. Clearly, the culture medium can provide several nutrients and favorable conditions to fungal development and growth, instead of cuticle, that biologically acts as a physical barrier (Ment et al., 2012; Barreto et al., 2016). Similar results were found by Barreto et al. (2016), where they analyzed conidial germination not only on the culture media but also on the cuticle surface. Additionally, oils can help conidia adhesion since its absence may limit aggregation (i.e., attachment among conidia rather than tick cuticle) and increase the number of free conidia that would germinate on the arthropod cuticle (Ment et al., 2010). Moreover, tick cuticle can contain natural inhibitors and fungistatic molecules (Kirkland et al., 2004) that could also hinder fungal germination (Sosa-Gomez et al., 1997; Kirkland et al., 2004) and make the penetration time longer. For these and other reasons, oil formulations, here exemplified by Metarril ${ }^{\circledR}$ SC, can be a choice to tick control and have the potential to be applied in further field tests.

A single engorged female can lay thousands of eggs after total engorgement; hence, one of the targets of fungal formulations is to diminish novel tick populations that will eventually infest the animals. Our assays demonstrate that the relevant results were observed on eggs and larvae for both products. Notably, Metarril ${ }^{\circledR}$ SC strongly reduced hatchability and increased larval mortality at the highest concentration tested. In agreement, many researchers have observed that the use of oil as an adjuvant enhances the fungal effect on eggs (Polar et al., 2005; Angelo et al., 2010; Camargo et al., 2012, 2014; Perinotto et al., 2017), perhaps by not only covering all the surface and reducing gas exchange but also by protecting the conidia and improving its action. For larvae - the most vulnerable stage to fungal infection (Kaay \& Hassan, 2000; Wassermann et al., 2016) - Metarril ${ }^{\circledR}$ SC at $10^{7}$ and $10^{8}$ conidia $\mathrm{mL}^{-1}$ presented similar results. As here, tests with Metarril ${ }^{\circledR} \mathrm{SC}$ to control unfed $A$. sculptum nymphs documented that $10^{7} \mathrm{conidia} \mathrm{mL}^{-1}$ was able to kill up to $60 \%$ of the nymphal population 10 days after treatment (Lopes et al., 2007). Its susceptibility might occur due to the cutaneous respiration and less or non-sclerotized exoskeleton present in larvae (Sonenshine \& Roe, 2014), however, further studies should be done to clarify these points and better understand its action prior to developing new tick fungal formulations. These outcomes lead the tick biocontrol to future focus on non-parasitic stages, either by spreading fungi directly onto the soil and acting as a reservoir or by using formulations that will scatter fungi from cattle feces on pasture. 


\section{Conclusions}

The current study demonstrated that the use of the oil-based product (Metarril ${ }^{\circledR} \mathrm{SC}$ ) is recommended instead of the dry conidia to be suspended in water (Metarril ${ }^{\circledR} \mathrm{SP}$ ) to all $R$. microplus stages. In addition, eggs and larvae were the most susceptible stages to the treatments, although high concentrations of conidia are still needed to ensure consistent results for ticks.

\section{Acknowledgements}

The present study was funded by the National Council for Scientific and Technological Development (CNPq) and the Carlos Chagas Filho Foundation for Research Support of the State of Rio de Janeiro (FAPERJ). We would also like to thank the Coordination for Improvement of Higher Education Personnel (CAPES) and Koppert ${ }^{\circledR}$ Biological Systems Company (formerly Itaforte ${ }^{\circledR}$ Bioproducts) for providing Metarrii ${ }^{\circledR}$ SP Organic and Metarril ${ }^{\circledR}$ SC Organic for this research.

\section{References}

Abbas RZ, Zaman MA, Colwell DD, Gilleard J, Iqbal Z. Acaricide resistance in cattle ticks and approaches to its management: the state of play. Vet Parasitol 2014; 203(1-2): 6-20. http://dx.doi.org/10.1016/j.vetpar.2014.03.006. PMid:24709006.

Alves FM, Bernardo CC, Paixão FRS, Barreto RP, Luz C, Humber RA, et al. Heat-stressed Metarhizium anisopliae: viability (in vitro) and virulence (in vivo) assessments against the tick Rhipicephalus sanguineus. Parasitol Res 2017; 116(1): 111-121. http://dx.doi. org/10.1007/s00436-016-5267-z. PMid:27704216.

Angelo IC, Fernandes EKK, Bahiense TC, Perinotto WMS, Moraes APR, Terra ALM, et al. Efficiency of Lecanicillium lecanii to control the tick Rhipicephalus microplus. Vet Parasitol 2010; 172(3-4):317-322. http://dx.doi.org/10.1016/j.vetpar.2010.04.038. PMid:20605335.

Aw KMS, Hue SM. Mode of infection of Metarhizium spp. fungus and their potential as biological control agents. J Fungi (Basel) 2017; 3(2): 30. http://dx.doi.org/10.3390/jof3020030. PMid:29371548.

Barreto LP, Luz C, Mascarin GM, Roberts DW, Arruda W, Fernandes EKK. Effect of heat stress and oil formulation on conidial germination of Metarhizium anisopliae s.s. on tick cuticle and artificial medium.J Invertebr Pathol 2016; 138: 94-103. http://dx.doi. org/10.1016/j.jip.2016.06.007. PMid:27317831.

Bennett GF. Oviposition of Boophilus microplus (Canestrini) (Acarida: Ixodidae). I. Influence of tick size on egg production. Acarologia 1974; 16(1): 52-61. PMid:4463680.

Beys-da-Silva WO, Rosa RL, Berger M, Coutinho-Rodrigues CJB, Vainstein MH, Schrank A, et al. Updating the application of Metarhizium anisopliae to control cattle tick Rhipicephalus microplus (Acari: ixodidae). Exp Parasitol 2020; 208: 107812. http:// dx.doi.org/10.1016/j.exppara.2019.107812. PMid:31809704.

Bischoff JF, Rehner SA, Humber RA. A multilocus phylogeny of the Metarhizium anisopliae lineage. Mycologia 2009; 101(4): 512530. http://dx.doi.org/10.3852/07-202. PMid:19623931.

Camargo MG, Golo PS, Angelo IC, Perinotto WMS, Sá FA, Quinelato S, et al. Effect of oil-based formulations of acaripathogenic fungi to control Rhipicephalus microplus ticks under laboratory conditions. Vet Parasitol 2012; 188(1-2): 140-147. http://dx.doi. org/10.1016/j.vetpar.2012.03.012. PMid:22480883.

Camargo MG, Marciano AF, Sá FA, Perinotto WMS, Quinelato S, Golo PS, et al. Commercial formulation of Metarhizium anisopliae for the control of Rhipicephalus microplus in a pen study. Vet Parasitol 2014; 205(1-2): 271-276. http://dx.doi.org/10.1016/j. vetpar.2014.07.011. PMid:25086495.

Camargo MG, Nogueira MRS, Marciano AF, Perinotto WMS, Coutinho-Rodrigues CJB, Scott FB, et al. Metarhizium anisopliae for controlling Rhipicephalus microplus ticks under field conditions. Vet Parasitol 2016; 223: 38-42. http://dx.doi.org/10.1016/j. vetpar.2016.04.014. PMid:27198775.

Drummond RO, Gladney WJ, Whetstone TM, Ernst SE. Laboratory testing of insecticides for control of the winter tick. J Econ Entomol 1971; 64(3): 686-688. http://dx.doi.org/10.1093/jee/64.3.686. PMid:5558278.

Faria MR, Wraight SP. Mycoinsecticides and mycoacaricides: a comprehensive list with worldwide coverage and international classification of formulation types. Biol Control 2007; 43(3): 237-256. http://dx.doi.org/10.1016/j.biocontrol.2007.08.001.

Fernandes ÉKK, Bittencourt VREP, Roberts DW. Perspectives on the potential of entomopathogenic fungi in biological control of ticks. Exp Parasito/ 2012; 130(3): 300-305. http://dx.doi.org/10.1016/j.exppara.2011.11.004. PMid:22143088. 
Ghosh S, Tiwari SS, Kumar B, Srivastava S, Sharma AK, Kumar S, et al. Identification of potential plant extracts for anti-tick activity against acaricide resistant cattle ticks, Rhipicephalus (Boophilus) microplus (Acari: ixodidae). Exp Appl Acarol 2015; 66(1): 159-171. http://dx.doi.org/10.1007/s10493-015-9890-7. PMid:25717008.

Grisi L, Leite RC, Martins JRS, Barros ATM, Andreotti R, Cançado PD, et al. Reassessment of the potential economic impact of cattle parasites in Brazil. Rev Bras Parasito/ Vet 2014; 23(2): 150-156. http://dx.doi.org/10.1590/S1984-29612014042. PMid:25054492.

Hedimbi M, Kaaya GP, Singh S, Chimwamurombe MP, Gindin G, Glazer I, et al. Protection of Metarhizium anisopliae conidia from ultra-violet radiation and their pathogenicity to Rhipicephalus evertsi evertsi ticks. In: Bruin J, Van Der Geest LPS, editors. Diseases of mites and ticks. Dordrecht: Springer; 2008. p. 149-156. http://dx.doi.org/10.1007/978-1-4020-9695-2_12

Hywel-Jones NL, Gillespie AT. Effect of temperature on spore germination in Metarhizium anisopliae and Beauveria bassiana. Mycol Res 1990; 94(3): 389-392. http://dx.doi.org/10.1016/S0953-7562(09)80363-8.

Jackson MA, Dunlap CA, Jaronski ST. Ecological considerations in producing and formulating fungal entomopathogens for use in insect biocontrol. BioControl 2010; 55(1): 129-145. http://dx.doi.org/10.1007/s10526-009-9240-y.

Kaay GP, Hassan S. Entomogenous fungi as promising biopesticides for tick control. Exp Appl Acarol 2000; 24(12): 913-926. http:// dx.doi.org/10.1023/A:1010722914299. PMid:11354619.

Kaaya GP, Samish M, Hedimbi M, Gindin G, Glazer I. Control of tick populations by spraying Metarhizium anisopliae conidia on cattle under field conditions. Exp Appl Acaro/ 2011; 55(3): 273-281. http://dx.doi.org/10.1007/s10493-011-9471-3. PMid:21725837.

Kirkland BH, Westwood GS, Keyhani NO. Pathogenicity of entomopathogenic fungi Beauveria bassiana and Metarhizium anisopliae to Ixodidae species Dermacentor variabilis, Rhipicephalus sanguineus, and Ixodes scapularis. J Med Entomo/ 2004; 41 (4): 705-711. http://dx.doi.org/10.1603/0022-2585-41.4.705. PMid:15311464.

Klafke G, Webster A, Dall Agnol B, Pradel E, Silva J, de La Canal LH, et al. Multiple resistance to acaricides in field populations of Rhipicephalus microplus from Rio Grande do Sul state, Southern Brazil. Ticks Tick Borne Dis 2017; 8(1): 73-80. http://dx.doi. org/10.1016/j.ttbdis.2016.09.019. PMid:27717758.

Lopes RB, Alves SB, Padulla LFL, Pérez CA. Eficiência de formulações de Beauveria bassiana e Metarhizium anisopliae para o controle de ninfas de Amblyomma cajennense (Fabricius, 1787). Rev Bras Parasitol Vet 2007; 16(1): 27-31. PMid:17588319.

Mascarin GM, Lopes RB, Delalibera IJr, Fernandes ÉKK, Luz C, Faria M. Current status and perspectives of fungal entomopathogens used for microbial control of arthropod pests in Brazil. J Invertebr Pathol 2019; 165: 46-53. http://dx.doi.org/10.1016/j. jip.2018.01.001. PMid:29339191.

Ment D, Churchill ALC, Gindin G, Belausov E, Glazer I, Rehner SA, et al. Resistant ticks inhibit Metarhizium infection prior to haemocoel invasion by reducing fungal viability on the cuticle surface. Environ Microbiol 2012; 14(6): 1570-1583. http://dx.doi. org/10.1111/j.1462-2920.2012.02747.x. PMid:22507442.

Ment D, Gindin G, Rot A, Soroker V, Glazer I, Barel S, et al. Novel technique for quantifying adhesion of Metarhizium anisopliae conidia to the tick cuticle. Appl Environ Microbio/ 2010; 76(11): 3521-3528. http://dx.doi.org/10.1128/AEM.02596-09. PMid:20363785.

Ment D, Shikano I, Glazer I. Abiotic factors. In: Hajek AE, Shapiro-Ilan DI, editors. Ecology of invertebrate diseases. Hoboken: WileyBlackwell; 2017. p. 143-186. http://dx.doi.org/10.1002/9781119256106.ch5

Merino O, Alberdi P, de la Lastra JMP, de la Fuente J. Tick vaccines and the control of tick-borne pathogens. Front Cell Infect Microbio/ 2013; 3: 30. http://dx.doi.org/10.3389/fcimb.2013.00030. PMid:23847771.

Oliveira DGP, Lopes RB, Rezende JM, Delalibera I Jr. Increased tolerance of Beauveria bassiana and Metarhizium anisopliae conidia to high temperature provided by oil-based formulations. J Invertebr Pathol 2018; 151: 151-157. http://dx.doi.org/10.1016/j. jip.2017.11.012. PMid:29175530.

Perinotto WMS, Angelo IC, Golo OS, Camargo MG, Quinelato S, Sá FA, et al. In vitro pathogenicity of different Metarhizium anisopliae s.I. isolates in oil formulations against Rhipicephalus microplus. Biocontrol Sci Technol 2017; 27(3): 338-347. http://dx.doi.org/10. 1080/09583157.2017.1289151.

Perinotto WMS, Camargo MG, Golo PS, Angelo IC, Quinelato S, Monteiro CMO, et al. Controle de Dermacentor nitens utilizando uma formulação comercial à base de Metarhizium anisopliae. Rev Bras Med Vet 2013; 35(Suppl Suppl.2): 35-42.

Pignati WA, Lima FANS, Lara SS, Correa MLM, Barbosa JR, Leão LHC, et al. Spatial distribution of pesticide use in Brazil: a strategy for Health Surveillance. Cien Saude Colet 2017; 22(10): 3281-3293. http://dx.doi.org/10.1590/1413-812320172210.17742017. PMid:29069184.

Polar P, Kairo MTK, Moore D, Pegram R, John S. Comparison of water, oils and emulsifiable adjuvant oils as formulating agents for Metarhizium anisopliae for use in control of Boophilus microplus. Mycopathologia 2005; 160(2): 151-157. http://dx.doi.org/10.1007/ s11046-005-0120-4. PMid:16170611. 
Prior C, Jollands P, Le Patourel G. Infectivity of oil and water formulation of Beauveria bassiana (Deuteromycotina: Hyphomycetes) to the cocoa weevil pest Pantorhytes plutus (Coleoptera: Curculionidae). J Invertebr Pathol 1988; 52(1): 66-72. http://dx.doi. org/10.1016/0022-2011(88)90103-6.

Quinelato S, Golo PS, Perinotto WMS, Sá FA, Camargo MG, Angelo IC, et al. Virulence potential of Metarhizium anisopliae s.I. isolates on Rhipicephalus (Boophilus) microplus larvae. Vet Parasito/ 2012; 190(3-4): 556-565. http://dx.doi.org/10.1016/j.vetpar.2012.06.028. PMid:22840642.

Reck J, Klafke GM, Webster A, Dall'Agnol B, Scheffer R, Souza UA, et al. First report of fluazuron resistance in Rhipicephalus microplus: A field tick population resistant to six classes of acaricides. Vet Parasitol 2014; 201(1-2): 128-136. http://dx.doi.org/10.1016/j. vetpar.2014.01.012. PMid:24560364.

Samish M, Rot A, Ment D, Barel S, Glazer I, Gindin G. Efficacy of the entomopathogenic fungus Metarhizium brunneum in controlling the tick Rhipicephalus annulatus under field conditions. Vet Parasitol 2014; 206(3-4): 258-266. http://dx.doi.org/10.1016/j. vetpar.2014.10.019. PMid:25468024.

Sampaio IBM. Estatística aplicada à experimentação animal. 4th ed. Belo Horizonte: Fundação de Estudo e Pesquisa em Medicina Veterinária e Zootecnia; 2015.

Sonenshine DE, Roe RM. Biology of ticks. New York: Oxford University Press; 2014. (vol. 2).

Sosa-Gomez DR, Boucias DG, Nation JL. Attachment of Metarhizium anisopliae to the southern green stink bug Nezara viridula cuticle and fungistatic effect of cuticular lipids and aldehydes. J Invertebr Pathol 1997; 69(1): 31-39. http://dx.doi.org/10.1006/ jipa.1996.4619. PMid:9028925.

Tomer H, Blum T, Arye I, Faigenboim A, Gottlieb Y, Ment D. Activity of native and commercial strains of Metarhizium spp. against the poultry red mite Dermanyssus gallinae under different environmental conditions. Vet Parasito/ 2018; 262: 20-25. http://dx.doi. org/10.1016/j.vetpar.2018.09.010. PMid:30389007.

Wassermann M, Selzer P, Steidle JLM, Mackenstedt U. Biological control of Ixodes ricinus larvae and nymphs with Metarhizium anisopliae blastospores. Ticks Tick Borne Dis 2016; 7(5): 768-771. http://dx.doi.org/10.1016/j.ttbdis.2016.03.010. PMid:27005430.

Zimmermann G. Review on safety of the entomopathogenic fungus Metarhizium anisopliae. Biocontrol Sci Technol 2007; 17(9): 879-920. http://dx.doi.org/10.1080/09583150701593963. 